\title{
Design and synthesis of 15-deoxyspergualin-biotin conjugates as novel binding probes for target protein screening
}

\author{
Masahiko Morioka ${ }^{1,2}$, Kuniki Kato ${ }^{1}$ and Kazuo Umezawa ${ }^{3}$ \\ The Journal of Antibiotics (2016) 69, 574-578; doi:10.1038/ja.2016.32; published online 23 March 2016
}

Spergualin 1 (Figure 1) was isolated in 1981 from the culture filtrate of Bacillus laterosporus as a novel anticancer antibiotic, and it inhibited the growth of chick embryo fibroblasts that had been transformed by Rous sarcoma virus. ${ }^{1,2}$ It was totally synthesized in $1985 .^{3}$ The antitumor effect of spergualin was considered to involve potentiation of cytotoxic T-lymphocytes. ${ }^{4}$ Spergualin showed not only anticancer activity against mouse leukemia tumors but also potent immunosuppressive activity in mice. ${ }^{5}$ In the course of a structure-activity relationship study, 15-deoxyspergualin (DSG; Figure 1) 2 was discovered in $1982,{ }^{6}$ and it showed $\sim 10$ times more potent than spergualin in the therapeutic activity. DSG showed six times prolongation of survival in L1210-bearing mice with $0.20 \mathrm{mg} \mathrm{kg}^{-1}$, whereas spergualin showed four times prolongation with $3.1 \mathrm{mg} \mathrm{kg}^{-1} .6$ DSG showed immunosuppressive activity in mice $^{7}$ and dogs. ${ }^{8}$ DSG was first evaluated as an anticancer agent and its clinical trial was carried out. Later, it was also found to be a potent immunosuppressive agent in clinical studies.

Studies on the target protein of DSG showed that heat-shock protein 70 (HSP70) would interact with DSG. ${ }^{9}$ Furthermore, DSG was also found to bind to HSP90. Both HSP70 and HSP90 possess the same EEVD motif, and this motif was considered to be the binding site. ${ }^{10}$ However, although DSG binds to the EEVD motif of HSP70, DSG did not affect the chaperone function of HSP70. ${ }^{11}$ Nadler et al. ${ }^{9}$ prepared an affinity resin by coupling the terminal amino group of the spermidine moiety of 11-methoxy-15-deoxyspergualin (Figure 1) 3, a stable derivative of DSG, to a sepharose resin. Using this affinity column, HSP70 was selectively trapped from the lysate of human T-cell leukemia Jurkat cells. However, modification of the primary amino group of 3 resulted in a loss of its immunosuppressive effect. ${ }^{12}$ Therefore, although DSG is known to bind to HSP70 and HSP90, these target proteins cannot explain the mechanism of the immunosuppressive effect of DSG. Thus, the essential target molecule remains unclear.
In the present research, we designed and synthesized 15-deoxyspergualin-biotin conjugates, BDSG-S and BDSG-L, having shorter and longer spacers in which the non-essential hydroxyl group was replaced by an aminoalkyl group.

An efficient synthesis of $( \pm)$-DSG and an enantioselective synthesis of ( - )-15-DSG have been reported. ${ }^{13,14}$ Presently, DSG is supplied by an industrial manufacturing method as the pharmaceutical product. ${ }^{15}$ From the study of biological activity of DSG and its structure - activity relationship, ${ }^{12}$ we deduced that a compound having the $\mathrm{N}$-biotinoyl4-aminoalkyl group instead of the hydroxyl group at position 11 of DSG would neither lose its immunosuppressive activity nor compromise its binding with the target protein. Based on this idea, we carried out a synthesis of BDSG 4 and $\mathbf{5}$ (Figure 2).

BDSG 4 was synthesized from known $N, N^{\prime}$-(bis-Cbz-guanidino) heptanoic acid 6 prepared from $N, N^{\prime}$-bis $(\mathrm{Cbz})-S$-methylisothiourea ${ }^{16}$ and 7-aminoheptanoic acid. First, coupling of compound 6 with commercially available $N^{\varepsilon}$-Boc-L-lysine allyl ester $7^{12}$ using the usual WSC/HOAt (water-soluble carbodiimide/1-hydroxy-7-azabenzotriazole) methodology provided the desired $\mathbf{8}$, which was subjected to cleavage of the allyl group using $\mathrm{Pd}\left(\mathrm{PPh}_{3}\right)_{4}$ and morpholine ${ }^{17}$ to provide the corresponding carboxylic acid $\mathbf{9}$ in quantitative yield, as shown in Scheme 1.

Next, $N^{1}, N^{5}$-bis-Cbz-spermidine $\mathbf{1 4}$ was synthesized as shown in Scheme 2. Condensation of spermidine $\mathbf{1 0}$ with formaldehyde in water followed by protection of the primary amine of the intermediate compound with 2-(Boc-oxyimino)-2-phenylacetonitrile (BocON) yielded tetrahydropyrimidine $\mathbf{1 1}$ protected with tert-butoxycarbonyl group (Boc) group at primary amino group in $28 \%$ yield in two steps. Subsequently, the resultant compound $\mathbf{1 1}$ was reacted with benzyl hydrogen malonate and pyridine to give $N^{10}$-Boc-protected spermidine 12. Then, $N^{1}$ primary amino group and $N^{5}$ secondary amino group of 12 were protected with benzyloxylcarbonyl chloride to give $N^{1}, N^{5}, N^{10}$ tri-functionalized spermidine $\mathbf{1 3}$ (25\% yield in two steps).

${ }^{1}$ Department of Applied Chemistry, Faculty of Science and Technology, Keio University, Yokohama, Japan; ${ }^{2}$ R\&D, Product and Service Development, CXS Corporation, Yokohama, Japan and ${ }^{3}$ Department of Molecular Target Medicine, Aichi Medical University School of Medicine, Aichi, Japan

Correspondence: Professor K Umezawa, Department of Molecular Target Medicine, Aichi Medical University School of Medicine, 1-1 Yazako-Karimata, Nagakute, Aichi 480-1195, Japan.

E-mail: umezawa@aichi-med-u.ac.jp

Received 27 November 2015; revised 4 February 2016; accepted 12 February 2016; published online 23 March 2016 
Next, the Boc group of $N^{10}$ of $\mathbf{1 2}$ was removed under acidic conditions to give $N^{1}, N^{5}$-bis-Cbz-spermidine 14 in almost quantitative yield.

Synthesis of the target compound BDSG 4 was accomplished as shown in Scheme 3. The coupling reaction between carboxylic acid 9 and bis-Cbz-spermidine $\mathbf{1 4}$ was achieved smoothly to afford compound $\mathbf{1 5}$ in $88 \%$ yield using the WSC/HOAt methodology. Then, the Boc group of the amine at position 16 of $\mathbf{1 5}$ was removed under acidic conditions to afford amine 16 , which was subsequently reacted with NHS-Biotin 17 in the presence of 4-dimethylaminopyridine (DMAP) in pyridine to afford the biotinylated compound 18 in $77 \%$ yield in two steps. Finally, complete deprotection of four Cbz groups of $\mathbf{1 8}$ was accomplished using hydrogenolysis over palladium hydroxide under a hydrogen atmosphere to give the target compound 4 (BDSG-S) in $58 \%$ yield and 5 (BDSG-L) in 57\% yield (Scheme 3 ). The structures of biotinylated agents for BDSG-S (17) and BDSG-L (19) as well as BDSG-L (5) are shown in Figure 3.

We have prepared compound 4 (BDSG-S) and 5 (BDSG-L) as biotin conjugates of DSG with linker. 15-DSG was reported to show anticancer and immunosuppressive activities in vivo. However, its cellular activity has been poorly understood so far. Therefore, it was difficult for us to compare the biological activity of 15-DSG and BDSGs. However, we found that 15-DSG efficiently inhibited the growth of mouse macrophage-like leukemia cell lines J774.1 and<smiles>N=C(N)NCCCC[C@H](O)CC(=O)NC(O)C(=O)NCCCCNCCCN</smiles><smiles>N=C(N)NCCCCCCC(=O)NC(O)C(=O)NCCCCNCCCN</smiles>

15-Deoxyspergualin (DSG) 2<smiles>COC(NC(=O)CCCCCCNC(=N)N)C(=O)NCCCCNCCCN</smiles>

Figure 1 Structures of spergualin and its derivatives.
RAW264.7. The 40\% inhibitory concentration (IC40) of DSG was $\sim 3 \mu \mathrm{g} \mathrm{ml}^{-1}$, whereas BDSG-S was $\sim 30 \mu \mathrm{g} \mathrm{ml}^{-1}$ to inhibit the growth of J774.1 cells. Then, we have used BDSG-S for the screening of molecular target in J774 cells. Using BDSG-S, we have determined an RNA-binding protein as a candidate target protein. Binding of BDSG$S$ to PCBP-2 was confirmed by preparing the recombinant protein for the in vitro binding and by the deletion mutant experiment. The result of target screening will be published elsewhere.

\section{EXPERIMENTAL PROCEDURE}

\section{General synthetic procedures}

${ }^{1} \mathrm{H}-\mathrm{NMR}(400 \mathrm{MHz})$ and ${ }^{13} \mathrm{C}-\mathrm{NMR}(100.5 \mathrm{MHz})$ spectra were obtained at an ambient temperature using an AVANCE 400 Bruker spectrometer (Hamburg, Germany) in dimethyl sulfoxide (DMSO)- $d_{6}, \mathrm{CDCl}_{3}$ or $\mathrm{D}_{2} \mathrm{O}$. Chemical shifts are reported in $\delta$ (p.p.m.) referenced to internal tetramethylsilane (0.00 p.p.m.), residual $\mathrm{CHCl}_{3}$ (7.26 p.p.m.) or DMSO (2.50 p.p.m.) for ${ }^{1} \mathrm{H}$ NMR and chloroform- $d_{1}$ (77.16 p.p.m.) for ${ }^{13} \mathrm{C} \mathrm{NMR}$, and the coupling constants $(J)$ are expressed in Hz. Mass spectra were measured on Thermo Scientic (Waltham, MA, USA) LTQ ORBITRAP XL mass spectrometer. For column chromatography, silica gel (MORITEX Purif-Pack SI $30 \mu \mathrm{m}$ ) or NH silica gel (MORITEX Purif-Pack NH $60 \mu \mathrm{m}$ ) was used. Optical rotations were observed with JASCO P-1020 polarimeter (Tokyo, Japan).

\section{(S)-6-((Boc)amino)-2- [7-(N,N'-Bis $(\mathrm{Cbz})$ guanidinoheptanamido $)]$} hexanoic acid (9)

To a solution of compound $\mathbf{6}(455 \mathrm{mg}, 1 \mathrm{mmol})$ and $N^{\varepsilon}$-Boc-L-lysine allyl ester $7(387 \mathrm{mg}, 1.2 \mathrm{mmol})$ in DMF $(5 \mathrm{ml})$ were added the following, at room temperature: WSC. $\mathrm{HCl}(210 \mathrm{mg}, 1.1 \mathrm{mmol})$, HOAt $(150 \mathrm{mg}, 1.1 \mathrm{mmol})$ and DIPEA $(0.70 \mathrm{ml}, 4.0 \mathrm{mmol})$. The resultant mixture was stirred at room temperature for $21 \mathrm{~h}$, the reaction mixture was added to $0.1 \mathrm{~N} \mathrm{HCl}$ aqueous solution $(10 \mathrm{ml})$ and then extracted with EtOAc three times. The combined organic layer was washed with brine, dried over anhydrous $\mathrm{MgSO}_{4}$ and concentrated under reduced pressure to give a viscous residue, which was used in the next reaction without further purification. After reacting the residue with $\mathrm{Pd}\left(\mathrm{PPh}_{3}\right)_{4}(116 \mathrm{mg}, 0.10 \mathrm{mmol})$ and morpholine $(870 \mu \mathrm{l}, 10 \mathrm{mmol})$ in THF $(3 \mathrm{ml})$ at room temperature for $4 \mathrm{~h}$, the reaction mixture was added to $0.1 \mathrm{~N} \mathrm{HCl}$ aqueous solution $(10 \mathrm{ml})$ and extracted with $t$-BuOMe three times. The combined organic layer was washed with brine, dried over anhydrous $\mathrm{MgSO}_{4}$ and concentrated under reduced pressure. The crude product was purified by silica gel column chromatography $(n$-hexane $/ \mathrm{AcOEt}=1: 1)$ to provide $\mathbf{9}(720 \mathrm{mg}$, yield: quant.) as an amorphous solid. ${ }^{1} \mathrm{H}-\mathrm{NMR}\left(\mathrm{DMSO}-d_{6}\right), \delta 12.40$ (br-s, $\left.1 \mathrm{H}\right), 11.59$

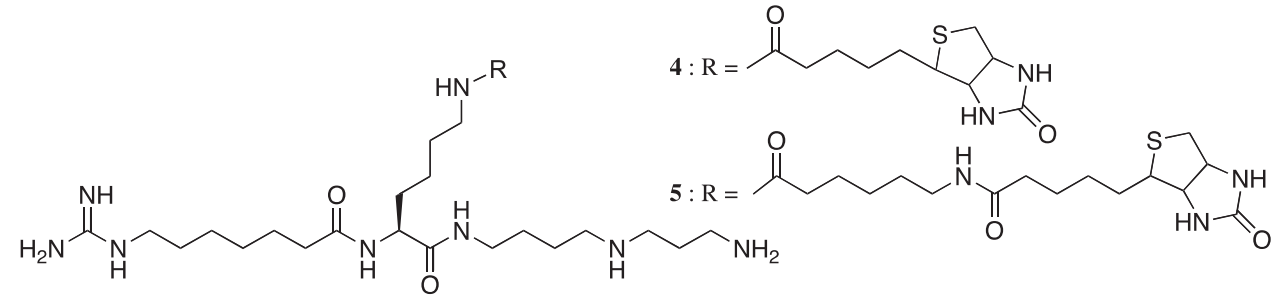

Figure 2 Molecular design of biotinylated 15-deoxyspergualins with short (BDSG-S) and long (BDSG-L) spacers.

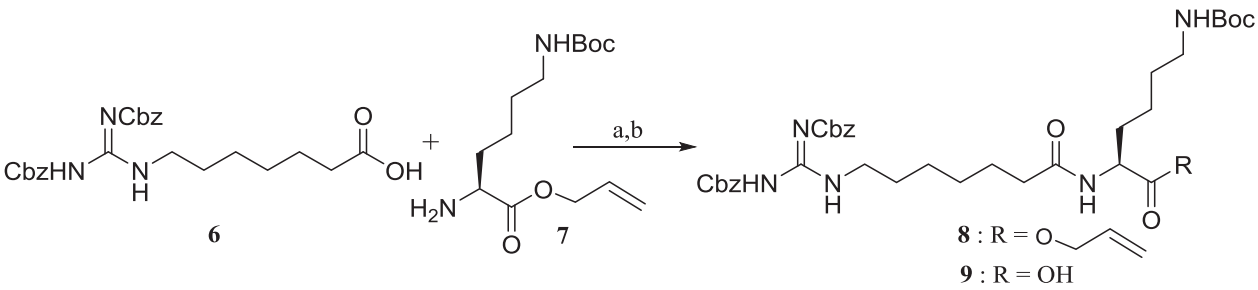

Scheme 1 Reagents and conditions: (a) water-soluble carbodiimide (WSC), 1-hydroxy-7-azabenzotriazole (HOAt), N, N-diisopropylethylamine (DIPEA), N,Ndimethylformamide (DMF), room temperature (rt), 21 h; (b) Pd(PPh3)4, morphorine, tetrahydrofuran (THF), rt, $2.5 \mathrm{~h}$. 


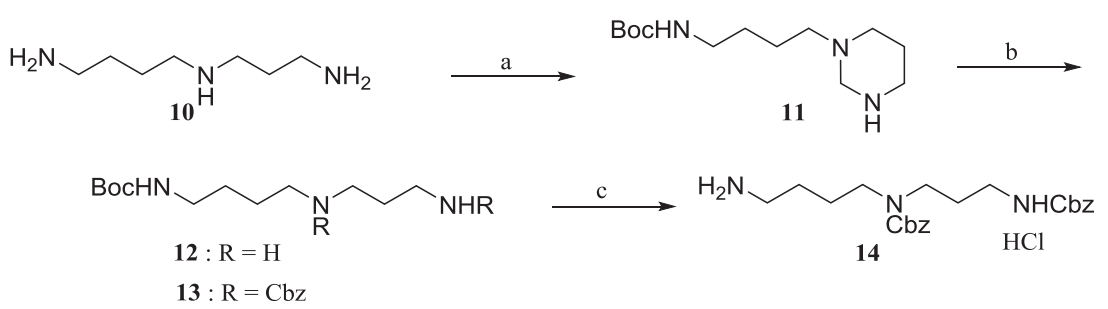

Scheme 2 Reagents and conditions: (a) $\mathrm{HCHO}, \mathrm{H}_{2} \mathrm{O}$, room temperature (rt), $72 \mathrm{~h}$, and then 2-(Boc-oxyimino)-2-phenylacetonitrile (BocON), THF, $0{ }^{\circ} \mathrm{C}, 0.5 \mathrm{~h}$; (b) $\mathrm{HOOCCH} 2 \mathrm{COOBn}$, pyridine-EtOH, reflux, $2 \mathrm{~h}$, and then $\mathrm{CbzCl}$, pyridine, rt, $20 \mathrm{~h}$; (c) $4 \mathrm{~N} \mathrm{HCl}$-dioxane, rt, $1 \mathrm{~h}$.

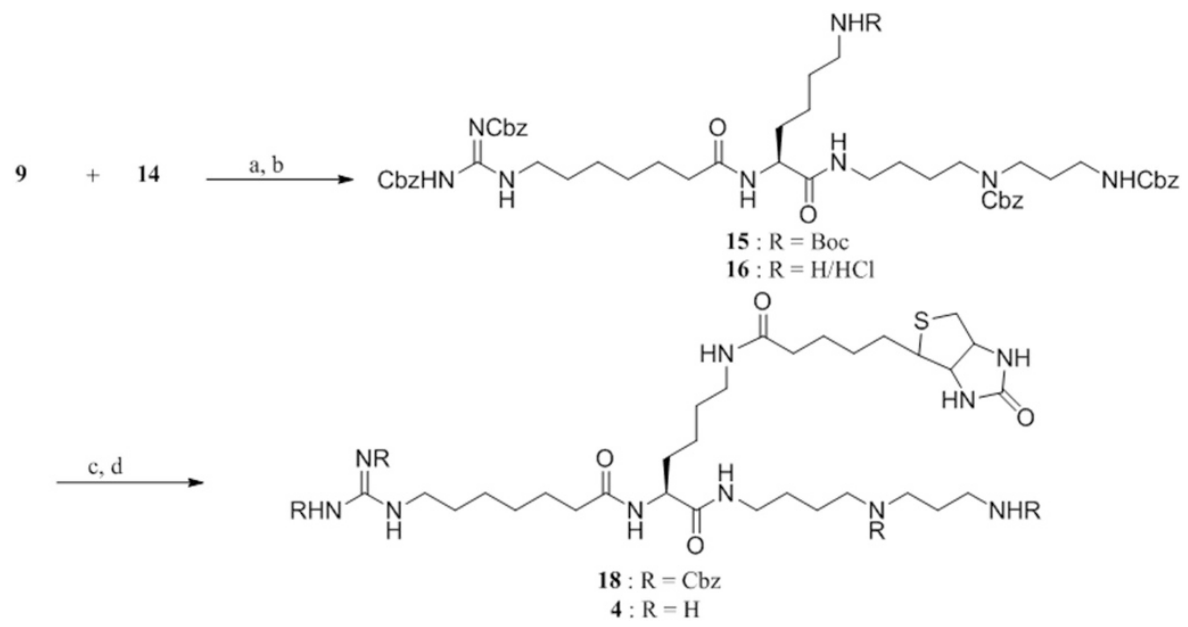

Scheme 3 Reagents and conditions: (a) water-soluble carbodiimide (WSC), 1-hydroxy-7-azabenzotriazole (HOAt), N,N-diisopropylethylamine (DIPEA), N,Ndimethylformamide (DMF), room temperature (rt), $19 \mathrm{~h}, 88 \%$; (b) $4 \mathrm{~N} \mathrm{HCl-dioxane,} \mathrm{rt,} 1 \mathrm{~h}, 87 \%$; (c) cat. 4-dimethylaminopyridine (DMAP), pyridine, 17, rt, 17 h, 33\%: (d) H2, $\mathrm{Pd}(\mathrm{OH}) 2, \mathrm{MeOH}$, rt, 5 h, 58\%.

(s, 1H), 8.39 (dd-like, 1H), 7.90 (d, 1H, J=5.8 Hz), 7.45-7.25 (complex, 10H), $5.21,5.03$ (each s, each $2 \mathrm{H}), 4.20-4.08(\mathrm{~m}, 1 \mathrm{H}), 3.40-3.25$ (complex, $2 \mathrm{H})$, 2.95-2.80 (complex, 2H), 2.15-2.05 (complex, 2H), 1.72-1.40 (complex, 6H), 1.38 (s, 9H), 1.40-0.85 (complex, 8H); HRMS (CI) calcd. for $\mathrm{C}_{35} \mathrm{H}_{49} \mathrm{~N}_{5} \mathrm{O}_{9}[\mathrm{M}]^{+}$ $=684.3603$. Found: 684.3612.; $[\alpha]^{24}{ }_{\mathrm{D}}+1.03^{\circ}(c$ 0.96, MeOH$)$.

\section{tert-Butyl 4-(tetrahydropyrimidin-1(2H)-yl)butylcarbamate (11)}

To a solution of spermidine $10(25 \mathrm{~g}, 172 \mathrm{mmol})$ in water $(200 \mathrm{ml})$ was added a $37 \%$ formaldehyde aqueous solution $(14.2 \mathrm{ml}, 189 \mathrm{mmol})$, and the resultant mixture was stirred at room temperature for 3 days. The reaction mixture was lyophilized to give the cyclic compound ( $23.2 \mathrm{~g}$, yield: $86 \%$ ), which was used in the next reaction without further purification. ${ }^{1} \mathrm{H}-\mathrm{NMR}\left(\mathrm{CDCl}_{3}\right), \delta 3.38$ (br-s, $2 \mathrm{H}), 2.81(\mathrm{t}, 2 \mathrm{H}, J=5.2 \mathrm{~Hz}), 2.71(\mathrm{t}, 2 \mathrm{H}, J=6.9 \mathrm{~Hz}), 2.57(\mathrm{br}-\mathrm{s}, 2 \mathrm{H}), 2.25(\mathrm{t}$, $2 \mathrm{H}, J=6.9 \mathrm{~Hz}$ ), 1.7-1.4 (complex, $8 \mathrm{H})$.

To a solution of previously obtained crude cyclic compound $(5.79 \mathrm{~g}$, $36.8 \mathrm{mmol})$ in THF $(100 \mathrm{ml})$ was added BocON $(7.3 \mathrm{~g}, 29.5 \mathrm{mmol})$ under ice-cold conditions and the resultant mixture was allowed to stand for $30 \mathrm{~min}$. After addition of aqueous solution of $0.5 \mathrm{~N}$ sodium hydroxide $(200 \mathrm{ml})$, the reaction mixture was extracted with $\mathrm{Et}_{2} \mathrm{O}$ three times. The combined organic extracts were washed with brine, dried over anhydrous $\mathrm{MgSO}_{4}$, filtered and the filtrate was concentrated under reduced pressure to give a slurry $(8.06 \mathrm{~g})$. The crude product was purified by $\mathrm{NH}$-silica gel column chromatography ( $n$-hexane/AcOEt $=1: 1)$ to give compound $11(2.40 \mathrm{~g}$, yield: $32 \%)$ as an amorphous solid. ${ }^{1} \mathrm{H}-\mathrm{NMR}\left(\mathrm{CDCl}_{3}\right), \delta 5.87$ (br-s, $\left.1 \mathrm{H}\right), 3.37$ (br-s, $\left.2 \mathrm{H}\right), 3.11$ (t-like, $2 \mathrm{H}, J=4.6 \mathrm{~Hz}$ ), 2.82 (br-s, $2 \mathrm{H}), 2.57$ (br-s, $2 \mathrm{H}), 2.23(\mathrm{t}, 2 \mathrm{H}, J=6.7 \mathrm{~Hz}$ ), 1.63 (dt-like, $2 \mathrm{H}), 1.55-1.50$ (complex, $4 \mathrm{H}), 1.45(\mathrm{~s}, 9 \mathrm{H}) ;{ }^{13} \mathrm{C}-\mathrm{NMR}\left(\mathrm{CDCl}_{3}\right), \delta$ $156.11,69.89,55.28,53.15,45.24,40.66,28.29,28.16,27.10,24.55$; HRMS (CI) calcd for $\mathrm{C}_{13} \mathrm{H}_{27} \mathrm{~N}_{3} \mathrm{O}_{2}[\mathrm{M}]^{+}=258.2176$. Found: 258.2178 .
Benzyl (3-(Cbz)amino)propyl-(4-(Boc)aminobutyl)-carbamate (13) To a solution of compound $11(2.00 \mathrm{~g}, 7.77 \mathrm{mmol})$ in EtOH $(100 \mathrm{ml})$ were added pyridine $(2.5 \mathrm{ml})$ and monobenzyl malonate $(6.0 \mathrm{~g}, 31 \mathrm{mmol})$ under ice-cold conditions and the resulting mixture was stirred at $80^{\circ} \mathrm{C}$ for $2 \mathrm{~h}$. The reaction mixture was concentrated under reduced pressure and the residue was roughly purified by $\mathrm{NH}$-silica gel column chromatography ( $n$-hexane/AcOEt $=1: 1)$ to give a slurry $(2.25 \mathrm{~g})$, which was used in the next reaction without further purification. To a solution of the previously obtained slurry in pyridine $(20 \mathrm{ml})$ was added $\mathrm{CbzCl}(3.3 \mathrm{ml}, 23.3 \mathrm{mmol})$ under ice-cold conditions and the resultant mixture was allowed to stand at room temperature for $17 \mathrm{~h}$. The reaction mixture was concentrated under reduced pressure and the residue was purified by $\mathrm{NH}$-silica gel column chromatography ( $n$-hexane/AcOEt $=1: 1)$ to give compound $13(1.00 \mathrm{~g}$, yield: $25 \%$ in two steps). ${ }^{1} \mathrm{H}-\mathrm{NMR}$ (DMSO- $d_{6}$ ) $\delta$ 7.40-7.25 (complex, 10H), 7.25 (br-s, 1H), 6.80 (br-s, 1H), 5.06 (s, 2H), 5.01 (s, 2H), 3.25-3.10 (complex, 4H), 2.98 (q-like, 2H), 2.89 (br-s, 2H), 1.70-1.58 (complex, 2H), 1.5-1.25 (complex, $4 \mathrm{H}$ ), 1.36 (s, 9H); HRMS (CI) calcd for $\mathrm{C}_{28} \mathrm{H}_{39} \mathrm{~N}_{3} \mathrm{O}_{6}[\mathrm{M}]^{+}=514.2911$. Found: 514.2914 .

\section{Benzyl (4-aminobutyl)-(3-(Cbz)aminopropyl)-carbamate (14)}

Compound $13(300 \mathrm{mg}, 0.584 \mathrm{mmol})$ was treated with $4 \mathrm{~N} \mathrm{HCl}$-dioxane (1:3, $5.0 \mathrm{ml}$ ) at room temperature for $1 \mathrm{~h}$ and concentrated under reduced pressure to give diCbz-protected spermidine 14 (262 $\mathrm{mg}$, yield: quant.), which was used to the next reaction without further purification. ${ }^{1} \mathrm{H}-\mathrm{NMR}$ (DMSO- $d_{6}$ ) $\delta 7.85$ (br-s, 2H), 7.40-7.25 (complex, 10H), 5.06, (s, 2H), 5.00 (s, 2H), 3.28-3.14 (complex, 4H), 2.99 (q-like, 2H), 2.76 (br-s, 2H), 1.75-1.60 (complex, 2H), 1.60-1.45 (complex, 4H); HRMS (CI) calcd for $\mathrm{C}_{23} \mathrm{H}_{31} \mathrm{~N}_{3} \mathrm{O}_{4}[\mathrm{M}]^{+}=414.2387$. Found: 414.2386 . 

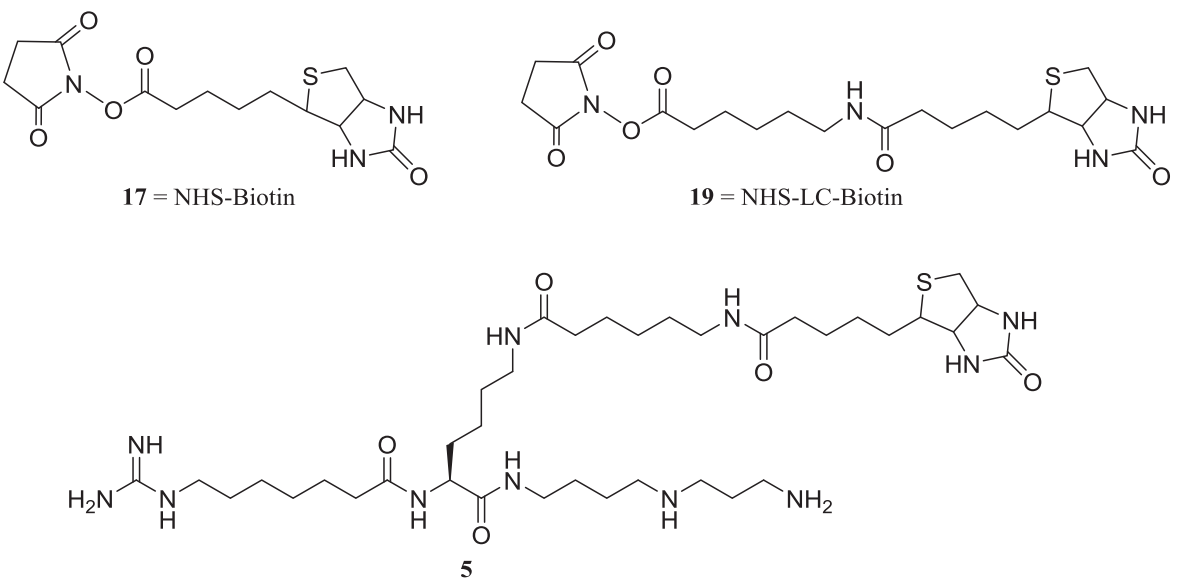

Figure 3 Biotinylated agents for biotinylated 15-deoxyspergualins with short (BDSG-S) (17) and long (BDSG-L) (19) spacers as well as BDSG-L (5).

(S)-N-(6-(Boc)amino-1-(4-(1,3-Bis (Cbz)aminopropylamino) butylamino)-1-oxohexan-2-yl)-7-(N,N'-Bis(Cbz)guanidino) heptanamide (15)

To a solution of compound 9 (720 mg, $1.0 \mathrm{mmol})$ in DMF $(5.0 \mathrm{ml})$ under icewater conditions were added DIPEA $(0.7 \mathrm{ml})$, diCbz-protected spermidine 14 (435 mg, $0.967 \mathrm{mmol})$, HOAt $(177 \mathrm{mg}, 1.3 \mathrm{mmol})$ and WSC. $\mathrm{HCl}(250 \mathrm{mg}$, $1.3 \mathrm{mmol}$ ) sequentially and the resultant mixture was stirred at room temperature for $20 \mathrm{~h}$. After addition of water $(30 \mathrm{ml})$, the reaction mixture was extracted with EtOAc and the organic layer was washed with brine, dried over anhydrous $\mathrm{MgSO}_{4}$ and concentrated under reduced pressure. The crude product was purified by silica gel column chromatography $(n$-hexane/AcOEt $=$ 1:1) to give compound $\mathbf{1 5}$ (925 mg, yield: $88 \%$ ) as an amorphous solid. ${ }^{1} \mathrm{H}-\mathrm{NMR}$ (DMSO- $d_{6}$ ), $\delta 11.58$ (s, 1H), 8.38 (dd-like, $1 \mathrm{H}$ ), 7.90-7.78 (complex, 2H), 7.45-7.20 (complex, 20H), $6.73(\mathrm{t}, 1 \mathrm{H}, J=4.4 \mathrm{~Hz}), 5.20(\mathrm{~s}, 2 \mathrm{H}), 5.05(\mathrm{~s}$, $2 \mathrm{H}), 5.03(\mathrm{~s}, 2 \mathrm{H}), 5.00(\mathrm{~s}, 2 \mathrm{H}), 4.20-4.08(\mathrm{~m}, 1 \mathrm{H}), 3.35-3.25$ (complex, $2 \mathrm{H}$ ), 3.25-3.10 (complex, 4H), 3.10-2.95 (complex, 4H), 2.90-2.75 (m, $1 \mathrm{H})$, 2.15-1.00 (complex, 2H), 1.70-1.20 (complex, 20H), 1.38 (s, 9H); HRMS (CI) calcd for $\mathrm{C}_{58} \mathrm{H}_{78} \mathrm{~N}_{8} \mathrm{O}_{12}[\mathrm{M}]^{+}=1079.5811$. Found: 1079.5814.; $[\alpha]^{24} \mathrm{D}$ $-4.24^{\circ}$ (c 0.96, $\left.\mathrm{MeOH}\right)$.

$\mathrm{N}$-((S)-1-(4-(3-aminopropylamino)butylamino)-1-oxo-6-(5-(2-oxohexahydro- $1 H$-thieno[3,4- $d]$ imidazol-4-yl)pentanamido)hexan-2yl)-7-guanidinoheptanamide (4)

Compound 15 (925 mg, $0.857 \mathrm{mmol}$ ) was dissolved in $4 \mathrm{~N} \mathrm{HCl}$-dioxane (1:3, $1.0 \mathrm{ml}$ ) and stirred at room temperature for $1 \mathrm{~h}$. The solvent was removed under reduced pressure to give the crude $\mathrm{HCl}$ salt of de-Boc compound 16 (760 mg), which was used in the next reaction without further purification. The deblocked compound $\mathbf{1 6}$ was dissolved in $4 \mathrm{ml}$ pyridine, from which $2 \mathrm{ml}$ was used. To the $2 \mathrm{ml}$ pyridine solution under ice-bath conditions was added NHSBiotin $17(83 \mathrm{mg}, 0.242 \mathrm{mmol})$ and the resultant mixture was stirred at $0{ }^{\circ} \mathrm{C}$ for $17 \mathrm{~h}$. The reaction mixture was concentrated under reduced pressure and the obtained crude product was purified by reverse phase silica gel chromatography (acetonitrile/water $=1: 1)$ to give compound $\mathbf{1 8}(75 \mathrm{mg}$, yield: $31 \%$ from 17$)$ as an amorphous solid. ${ }^{1} \mathrm{H}-\mathrm{NMR}\left(\mathrm{CDCl}_{3}\right), \delta 11.58(\mathrm{~s}, 1 \mathrm{H}), 8.39(\mathrm{t}, 1 \mathrm{H}$, $J=3.8 \mathrm{~Hz}), 7.90-7.78$ (complex, $2 \mathrm{H}), 7.72(\mathrm{t}, 1 \mathrm{H}, J=4.1 \mathrm{~Hz}), 7.45-7.20$ (complex, 20H), $6.42(\mathrm{~s}, 1 \mathrm{H}), 6.36(\mathrm{~s}, 1 \mathrm{H}), 5.30(\mathrm{~s}, 2 \mathrm{H}), 5.05(\mathrm{~s}, 2 \mathrm{H}), 5.03$ $(\mathrm{s}, 2 \mathrm{H}), 5.00(\mathrm{~s}, 2 \mathrm{H}), 4.29(\mathrm{dd}, 1 \mathrm{H}, J=2.7$ and $3.9 \mathrm{~Hz}$ ), 4.20-4.00 (complex, 2H), 3.40-3.20 (complex, 2H), 3.20-3.10 (complex, 4H), 3.10-2.90 (complex, 7H), 2.85-2.72 (dd-like, $1 \mathrm{H}), 2.60-2.50$ (m, 1H), 2.15-1.95 (complex, 4H), 1.70-1.10 (complex, 27H); HRMS (CI) calcd for $\mathrm{C}_{63} \mathrm{H}_{84} \mathrm{~N}_{10} \mathrm{O}_{12} \mathrm{~S}[\mathrm{M}+\mathrm{H}]^{+}$ $=1205.6063$. Found: 1205.6052 .

Then, compound 18 was dissolved in methanol $(1.0 \mathrm{ml})$ and hydrogenated for $5 \mathrm{~h}$ in the presence of palladium hydroxide $\left(5 \mathrm{mg}\right.$ ) as a catalyst under a $\mathrm{H}_{2}$ atmosphere. After filtration of the mixture through a Celite pad, the filtrate was concentrated under reduced pressure. The crude product was purified by reverse phase silica gel chromatography (acetonitrile/water $=1: 1$ ) to give the target compound, BDSG 4 (24.2 mg, yield: 58\%). ${ }^{1} \mathrm{H}-\mathrm{NMR}\left(\mathrm{D}_{2} \mathrm{O}\right), \delta 4.65-4.58$ $(\mathrm{m}, 1 \mathrm{H}), 4.44-4.35(\mathrm{~m}, 1 \mathrm{H}), 4.18-4.08(\mathrm{~m}, 1 \mathrm{H}), 3.33(\mathrm{~m}, 1 \mathrm{H}$, overlapped with $\mathrm{H}_{2} \mathrm{O}$ ), 3.26-2.93 (complex, $\left.13 \mathrm{H}\right), 2.80-2.70(\mathrm{~m}, 1 \mathrm{H}), 2.37-2.20$ (complex, $4 \mathrm{H}$ ), 2.18-2.00 (complex, 2H), 1.82-1.47 (complex, 16H), 1.45-1.27 (complex, 8H); ${ }^{13} \mathrm{C}-\mathrm{NMR}\left(\mathrm{D}_{2} \mathrm{O}\right), \delta 177.22,176.56,174.36,165.28,163.13,156.62,117.74$, $114.84,62.07,60.21,55.42,54.12,48.80,47.29,44.38,41.04,39.64,38.85$, $38.36,35.41,35.25,30.54,27.83,27.75,27.70,27.64,25.84,25.51,25.47,25.14$, 23.67, 22.84, 22.61; HRMS (CI) calcd for $\mathrm{C}_{31} \mathrm{H}_{60} \mathrm{~N}_{10} \mathrm{O}_{4} \mathrm{~S}[\mathrm{M}]^{+}=669.4598$. Found: 669.4597.

\section{$\mathrm{N}$-((S)-1-amino-10,17,24-trioxo-28-(2-oxo-hexahydro-1H-thieno} [3,4-d] imidazol-4-yl)-4,9,16,23-tetraazaoctacosan-11-yl)-7guanidinoheptanamide (5)

In a similar procedure, the target compound 5 was prepared from 16 and NHSLC-Biotin 19 in $57 \%$ overall yield in three steps. ${ }^{1} \mathrm{H}-\mathrm{NMR}\left(\mathrm{D}_{2} \mathrm{O}\right), \delta 4.64-4.56$ $(\mathrm{m}, 1 \mathrm{H}), 4.44-4.37(\mathrm{~m}, 1 \mathrm{H}), 4.15-4.08(\mathrm{~m}, 1 \mathrm{H}), 3.35(\mathrm{~m}, 1 \mathrm{H}$, overlapped with $\mathrm{H}_{2} \mathrm{O}$ ), 3.35-3.05 (complex, 15H), 2.98 (dd, $1 \mathrm{H}, J=4.9$ and $13.0 \mathrm{~Hz}$ ), 2.76 (d, 1H), 2.33-2.20 (complex, 6H), 2.22-2.02 (complex, 2H), 1.80-1.46 (complex, 22H), 1.45-1.26 (complex, $10 \mathrm{H}) ;{ }^{13} \mathrm{C}-\mathrm{NMR}\left(\mathrm{D}_{2} \mathrm{O}\right), \delta 177.25$, $177.66,176.52,174.33,165.29,156.63,114.84,62.06,60.21,55.39,54.10$, $48.80,47.30,44.48,44.39,41.05,39.68,39.01,38.85,38.37,36.48,35.65,35.49$, $35.26,30.52,27.98,27.84,27.77,27.71,27.67,25.53,25.48,25.22,25.13,25.04$, 23.68, 22.85, 22.58, 22.16; HRMS (CI) calcd for $\mathrm{C}_{37} \mathrm{H}_{71} \mathrm{~N}_{11} \mathrm{O}_{5} \mathrm{~S}[\mathrm{M}]^{+}$ $=781.5360$. Found: 782.5413 .

\section{CONFLICT OF INTEREST}

The authors declare no conflict of interest.

\section{ACKNOWLEDGEMENTS}

This work was supported, in part, by MEXT-Supported Program for the Strategic Research Foundation at Private Universities, which is for Aichi Medical University 2011-2015 (S1101027).

1 Takeuchi, T. et al. A new antitumor antibiotic, spergualin: isolation and antitumor activity. J. Antibiot. 34, 1619-1621 (1981)

2 Umezawa, H. et al. Structure of an antitumor antibiotic, spergualin. J. Antibiot. 34, 1622-1624 (1981)

3 Kondo, S. et al. The total synthesis of spergualin, an antitumor antibiotic. J. Antibiot. 34, 1625-1627 (1981)

4 Umezawa, $\mathrm{H}$. et al. Involvement of cytotoxic T-lymphocytes in the antitumor activity of spergualin against L1210 cells. Cancer Res. 47, 3062-3065 (1987)

5 Umezawa, H. et al. Suppression of tissue graft rejection by spergualin. J. Antibiot. 36 283-284 (1985) 
6 Kondo, S., Takeuchi, T. \& Umezawa, H. A new antitumor antibiotic spergualin. Trends Antibiot. Res. 146-153 (1982)

7 Nemoto, K. et al. Immunosuppressive activities of 15-deoxyspergualin in animals. J. Antibiot. 40, 561-562 (1987)

8 Nemoto, K. et al. Suppression of humoral immunity in dogs by 15-deoxyspergualin. J. Antibiot. 40, 1065-1066 (1987)

9 Nadler, S. G., Tepper, M. A., Schacter, B. \& Mazzucco, C. E. Interaction of the immunosuppressant deoxyspergualin with a member of the Hsp70 family of heat shock proteins. Science 258, 484-486 (1992).

10 Nadeau, K., Nadler, S. G., Saulnier, M., Tepper, M. A. \& Walsh, C. T. Quantitation of the interaction of the immunosuppressant deoxyspergualin and analogs with $\mathrm{Hsc} 70$ and Hsp90. Biochemistry 33, 2561-2567 (1994).

11 Nadlar, S. G. et al. Identification of a binding site on Hsc70 for the immunosuppressant 15-deoxyspergualin. Biochem. Biophys. Res. Commun. 253, $176-180$ (1998)
12 Maeda, K., Umeda, Y. \& Saino, T. Synthesis and background chemistry of 15-deoxyspergualin. Ann. NY Acad. Sci. 685, 123-135 (1993).

13 Durand, P., Peralba, P. \& Rnant, P. A new efficient synthesis of the immunosuppressive agent ( \pm )-15-deoxyspergualin. Tetrahedron 57, 2757-2760 (2001).

14 Durand, P., Peralba, P. \& Rnant, P. (-)-15-Deoxyspergualin: a new and efficient enantioselective synthesis which allows the definitive assignment of the absolute configuration. J. Org. Chem. 63, 9723-9727 (1998).

15 Ponasik, J. A., Kassab, D. J. \& Ganem, B. Synthesis of the antifouling polyamine pseudoceratidine and its analogs: factor influencing biocidal activity. Tetrahedron Lett. 37, 6041-6044 (1996).

16 Gers, T., Kunce, D., Markowski, P. \& Izdebski, J. Reagents for efficient conversion of amines to protected guanidines. Synthesis 37-42 (2004).

17 Guibé, F. Tetrahedron, allylic protecting groups and their use in a complex environment. Part II. Allylic protecting groups and their removal through catalytic pardium $\pi$. Allyl Methodol. 54, 2967-3042 (1998). 